\title{
Speciation of Iron in Rain Water by Size Fractionation, Acid Decomposition, Acid Extraction and Catalytic Determination
}

\author{
Susumu KaWAKUBO ${ }^{\dagger}$ and Masaaki IwatsukI \\ Department of Applied Chemistry and Biotechnology, Faculty of Engineering, Yamanashi University, \\ Takeda, Kofu 400-8511, Japan
}

\begin{abstract}
For the speciation of trace iron in rain water, the concentration $\left(C_{\mathrm{L}}\right)$ of labile iron was determined by a catalytic spectrophotometric method based on the oxidation of $o$-phenylenediamine with hydrogen peroxide. The total concentration $\left(C_{\mathrm{T}}\right)$ of iron was determined by the same method after acid decomposition to obtain the concentration $\left(C_{\mathrm{T}}-C_{\mathrm{L}}\right)$ of non-labile iron. For the particle fraction (particle size $\left.\geq 0.45 \mu \mathrm{m}\right), 0.1 \mathrm{M} \mathrm{HCl}$-soluble iron was determined by atomic absorption spectrometry. Coexisting humic substances were spectrofluorometrically determined as humic acid. Labile iron was found in the fraction of molecular weight $(\mathrm{MW})<10^{3}$ and estimated as $\mathrm{FeOH}^{2+}$ and $\mathrm{Fe}(\mathrm{OH})_{2}{ }^{+}$from the chemical equilibria of hydroxo iron(III) ions. Non-labile iron was found in the particle fraction and characterized as acidsoluble iron hydroxide and humic iron aggregates as well as acid-insoluble compounds, like oxides and silicates. Labile iron was also found in the particle fraction of initial rainfall samples and characterized as iron complexed on humic iron aggregates. The above speciation results were confirmed by the analysis of synthetic samples.
\end{abstract}

(Received March 23, 2000; Accepted June 2, 2000)

The bioavailability and toxicity of metal species in aquatic systems may depend on the lability, i.e., reactivity, which is different depending on their chemical forms ${ }^{1,2}$ Especially, the association of iron with coexisting humic substances (HSs) changes the lability of iron. ${ }^{3}$ The aggregation of iron and HSs probably influences the lability of other trace constituents by their association with iron-HSs aggregates. ${ }^{4,5}$ Therefore, the speciation of labile and non-labile iron species is important in environmental and biological studies.

Iron can be sensitively determined at $\mathrm{pH}$ values close to those $\mathrm{e}^{6}$ of natural rain water by a catalytic spectrophotometric method using an iron-catalyzed oxidation reaction of $o$ phenylenediamine (OPDA) with hydrogen peroxide. ${ }^{3}$ The determination of iron is based on a measurement of the formation rate of oxidized OPDA in proportion to the concentration of iron forming an active intermediate, probably $\mathrm{Fe}^{\mathrm{III}}\left(\mathrm{H}_{2} \mathrm{O}_{2}\right)(\mathrm{OPDA})$, in the catalytic reaction process. Such a labile form of iron was well characterized as $\mathrm{Fe}^{3+}$ and $\mathrm{Fe}^{\mathrm{III}} \mathrm{L}_{i}^{(3-i n)+}$, where $i=1$ or 2 for unidentate and $i=1$ for bidentate ligand of $\mathrm{L}^{n-}$, in a study of the reactivity of hydroxo, fluoro and oxalato complexes of iron. ${ }^{3}$ Therefore, the interpretation of the lability is very simple compared with electrochemical methods, ${ }^{7,8}$ which are affected by the complicated adsorption property of the organic matter on a working electrode. In this paper, the catalytic method was combined with the size fractionation and acid decomposition, and was applied to the speciation of labile and non-labile iron in rain water. Acid extraction of the particle fraction was also carried out for the speciation. The analytical results of natural rain-water samples were compared with those of synthetic samples. The proposed method was simpler than the speciation method $^{9}$ based on the sorption separation with

$\doteqdot$ To whom correspondence should be addressed. four types of ion-exchangers and adsorbents.

\section{Experimental}

\section{Reagents and samples}

Unless stated otherwise, all chemicals were of analyticalreagent grade. High-purity $\mathrm{NaOH}$ and $\mathrm{HNO}_{3}$ solutions (Kanto Chemical Co., Inc., Ultrapur) and de-ionized and distilled water were used throughout. An iron stock standard solution (1.00 g $\mathrm{Fe}^{-1}$ ) was prepared by dissolving $\mathrm{FeNH}_{4}\left(\mathrm{SO}_{4}\right)_{2} \cdot 12 \mathrm{H}_{2} \mathrm{O}$ (purity $\geq 99.0 \%$ ) in $0.1 \mathrm{M} \mathrm{HCl}$. Working iron standard solutions were prepared just before use by diluting the stock standard solution with water or $1 \mathrm{mM} \mathrm{HCl}$ for a spectrophotometric determination or with $0.1 \mathrm{M} \mathrm{HCl}$ for an atomic-absorption spectrometric determination. A humic acid (HA) solution was prepared by dissolving the reagent of humic acid (Wako Pure Chemical Industries, Ltd., isolated from soil) in $0.01 \mathrm{M} \mathrm{NaOH}$ and was neutralized with $0.2 \mathrm{M} \mathrm{HCl}$.

In three rainfall events on 1/19/1999, 1/24/1999 and $9 / 16 / 1999$, rain water was collected on the roof of a building in Yamanashi University, Kofu, as the initial rainfall water from the beginning to $2 \mathrm{~mm}$ of rain precipitation, and as the successive rainfall water between $5 \mathrm{~mm}$ and $7 \mathrm{~mm}$. The total precipitations on 1/19/1999, 1/24/1999 and 9/19/1999 were 2.3, 6.6 and $1.3 \mathrm{~mm}$, respectively. The $\mathrm{pH}$ values for the initial rainfall sample on $1 / 19 / 1999$, the initial and successive samples on $1 / 24 / 1999$ and the initial sample on $9 / 19 / 1999$ were 4.38 , $4.15,4.49$ and 4.34 , respectively. Synthetic rain water samples were prepared by mixing iron(III) and/or HA solutions and by diluting immediately to $100 \mathrm{ml}$ with water. The $\mathrm{pH}$ value of the solutions was adjusted to 4.5 by adding an appropriate volume of $0.1 \mathrm{M} \mathrm{HCl}$ or $\mathrm{NaOH}$ before dilution. The synthetic samples 
were subjected to speciation after equilibrating for $24 \mathrm{~h}$ at $25^{\circ} \mathrm{C}$ in polystyrene bottles.

\section{Apparatus}

A laboratory-made sampler was used to collect rain water (140 $\mathrm{ml}$ for 2-mm rain precipitation) in the initial and successive rainfalls. Rain water was collected through a polyethylene funnel and stored into polystyrene containers. The sampler was set at an open place for the direct collection of rain water.

Ultrafiltration was carried out using ultrafilters (Pall Filtron, $1 \mathrm{~K}$ Microsep and 10K Macrosep) with nominal cut-off values of $10^{3}$ and $10^{4}$ daltons, respectively, as molecular weights $\left(10^{4}\right.$ daltons, corresponding to a pore size of about $1 \mathrm{~nm}$ ). The ultrafilters were washed by filtrations with $0.05 \mathrm{M}$ aqueous ammonia and then water to avoid contamination from the filter materials. A filter unit (Advantec Toyo, DISMIC-25, with a pore size of $0.45 \mu \mathrm{m}$ ) was used to fractionate particulate matter without any washing.

The determination of iron was carried out using a doublebeam spectrophotometer (Shimadzu, UV-160A) equipped with a $10 \mathrm{~mm}$ glass cell. The cell was controlled at a constant temperature by circulating water to the cell chamber from a thermostated water bath. Iron in the acid extracts was determined by using an atomic absorption spectrophotometer (Hitachi, 180-30) equipped with a $\mathrm{C}_{2} \mathrm{H}_{2}$-air flame burner. The determination of HSs was carried out using a spectrofluorometer (Shimadzu, RF-5000) equipped with a 10 mm silica glass cell. A clean hood (Air Tech Japan, MAC$10 \mathrm{~F} / \mathrm{V}$ ) and a clean bench (Shimadzu, SBC-1000A) were used for the acid decomposition and acid extraction in order to prevent environmental contamination. A pH meter (Horiba, F-14) was used for $\mathrm{pH}$ measurements within an error of about \pm 0.03 .

\section{Speciation procedure}

Figure 1 shows the scheme of the speciation procedure. The labile iron was determined as described previously. ${ }^{3}$ The sample (1 to $2 \mathrm{ml}$ ) was placed in a glass test tube. The temperature of the solution was adjusted to $40^{\circ} \mathrm{C}$. Iron was reacted at $\mathrm{pH} 4.5$ and $40^{\circ} \mathrm{C}$ in a $5-\mathrm{ml}$ solution with $4 \mathrm{mM}$ OPDA, $20 \mathrm{mM}$ hydrogen peroxide, $67.4 \mathrm{mM}$ acetic acid and 50 $\mathrm{mM}$ sodium acetate. The absorbances $\left(A_{1}\right.$ and $A_{2}$ at $\left.450 \mathrm{~nm}\right)$ of oxidized OPDA against water were measured at reaction times of $t_{1}=5$ and $t_{2}=10 \mathrm{~min}$, respectively. The labile concentration $\left(C_{\mathrm{L}}\right)$ of iron was determined from the formation rate of oxidized OPDA as $\left(A_{2}-A_{1}\right) /\left(t_{2}-t_{1}\right)=\left(A_{2}-A_{1}\right) / 5$.

For the determination of the total concentration $\left(C_{\mathrm{T}}\right)$ of iron, 10 or $12 \mathrm{ml}$ of a sample was placed in a PTFE vessel and decomposed by heating with $\mathrm{HF}, \mathrm{HNO}_{3}$ and $\mathrm{H}_{2} \mathrm{SO}_{4}$ at about $120^{\circ} \mathrm{C}^{10}$ The solution was evaporated to be about $0.01 \mathrm{ml}$ (a drop size of about $3 \mathrm{~mm}$ ). The residue was dissolved four times with $2 \mathrm{ml}$ of water under ultrasonication. An aliquot of the solution was subjected to a spectrophotometric determination of iron, as described above. The concentration $\left(C_{\mathrm{N}}\right)$ of non-labile iron was calculated as $C_{\mathrm{T}}-C_{\mathrm{L}}$. The concentrations of labile $\left(C_{\mathrm{L}}\right)$ and non-labile $\left(C_{\mathrm{N}}\right)$ iron in each size fraction were calculated; e.g., for the $10^{3} \leq$ molecular weights $(\mathrm{MW})<10^{4}$ fraction, $C_{\mathrm{L}}=$ $C_{\mathrm{L}, 2}-C_{\mathrm{L}, 3}$ and $C_{\mathrm{N}}=C_{\mathrm{T}, 2}-C_{\mathrm{T}, 3}+C_{\mathrm{L}, 3}-C_{\mathrm{L}, 2}$ (see Fig. 1 ).

The concentration of HSs was determined as HA by fluorescent measurement $\left(\lambda_{\mathrm{ex}}=270 \mathrm{~nm} ; \lambda_{\mathrm{em}}=460 \mathrm{~nm}\right)$ after adding a tartrate-citrate-borate solution for masking the interference of iron and adjusting $\mathrm{pH}$ to $10 .{ }^{11}$

The residue on the $0.45-\mu \mathrm{m}$ filter was stored in a desiccator. In clean bench or hood, iron and HSs were extracted by passing $60 \mathrm{ml}$ of $0.1 \mathrm{M} \mathrm{HCl}$ at a controlled flow rate through the filter

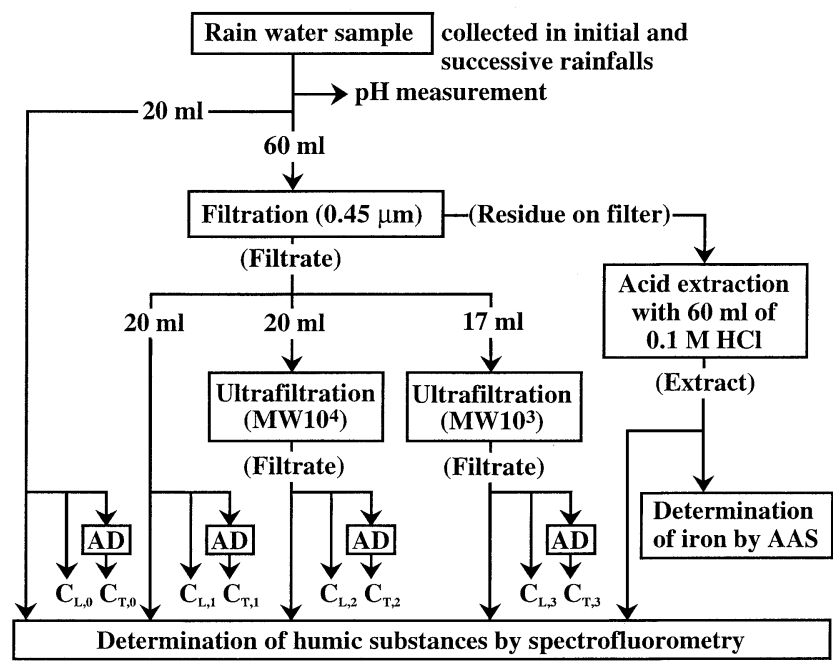

Fig. 1 Scheme of the speciation procedure. $C_{\mathrm{L}}$ and $C_{\mathrm{T}}$, labile and total concentrations of iron, respectively, determined by catalytic spectrophotometry; AD, acid decomposition; AAS, atomic absorption spectrometry.

for about $6 \mathrm{~h}$. Iron was determined by flame atomic absorption spectrometry (the catalytic method can be also used ${ }^{3}$ ). HSs were determined as described above.

\section{Results and Discussion}

\section{Analytical performances}

Errors in the catalytic spectrophotometric and fluorometric determinations were $\pm 0.3 \mu \mathrm{g}^{-1}$ for Fe and $\pm 6 \mu \mathrm{g} \mathrm{l}^{-1}$ for HA in the analysis of $2 \mathrm{ml}$ of the sample solution. The error in the flame atomic absorption spectrometry was typically $\pm 2 \mu \mathrm{g} \mathrm{l}^{-1}$ for $\mathrm{Fe}$. The contamination from ultrafilter materials was checked by determining the iron and HA in water which passed through the filters after the washing. For a $0.45-\mu \mathrm{m}$ filter, because no contamination was found, it was not washed. The washing of ultrafilters with aqueous ammonia could decrease the contamination to a negligible level of iron. The use of a high-purity $\mathrm{HNO}_{3}$ reagent and a clean hood allowed decomposition with a negligible contamination level. Satisfactory recoveries $(100 \pm 2 \%, n=8)$ in the acid decomposition were obtained for 0.4 or $1 \mu \mathrm{g}$ Fe added to a natural rain-water sample.

\section{Acid extraction}

The chemical form of iron in the particle fraction $(\geq 0.45 \mu \mathrm{m})$ on the filter was estimated from the solubility of iron into $0.1 \mathrm{M}$ $\mathrm{HCl}$ by passing it through the filter for about $6 \mathrm{~h}$. The concentration of $\mathrm{HCl}$ was selected to extract the iron species existing as hydroxides without dissolving its silicates or oxides from the atmospheric dust. ${ }^{12}$ At this concentration, a humic iron complex liberates iron ions. ${ }^{13,14}$

Table 1 gives the extraction results for natural and synthetic rain samples. Iron in the particle fraction for synthetic samples containing iron(III) alone or together with HA was completely extracted $(<0.45 \mu \mathrm{m})$ with $0.1 \mathrm{M} \mathrm{HCl}$ (Table 1, Nos. 3 and 4). On the other hand, for natural samples (Table 1, Nos. 1 and 2), large parts of iron and HA were incompletely extracted with 0.1 $\mathrm{M} \mathrm{HCl}$. The incomplete extraction of HA was ascribed to the formation of protonated HA aggregates. ${ }^{13}$ These extraction 
Table 1 Acid extraction results of iron and humic acid in the particle fraction $(\geq 0.45 \mu \mathrm{m})$ for natural and synthetic rain samples

\begin{tabular}{|c|c|c|c|c|c|}
\hline \multicolumn{3}{|c|}{$\mathrm{Fe} / \mu \mathrm{g} \mathrm{l}^{-1}$} & \multicolumn{3}{|c|}{ Humic acid/ $\mu g \mathrm{l}^{-1}$} \\
\hline A. Total & B. Extracted & $\mathrm{A}-\mathrm{B}$ & A. Total & B. Extracted & $\mathrm{A}-\mathrm{B}$ \\
\hline \multicolumn{6}{|c|}{ No. 1 Initial rainfall sample on $1 / 19 / 1999$} \\
\hline $207 \pm 12$ & $\begin{array}{c}91 \pm 1 \\
{[44 \pm 3]}\end{array}$ & $\begin{array}{l}116 \pm 12 \\
{[56 \pm 7]}\end{array}$ & $70 \pm 11$ & $\begin{array}{c}19 \pm 5 \\
{[27 \pm 8]}\end{array}$ & $\begin{array}{c}51 \pm 12 \\
{[73 \pm 21]}\end{array}$ \\
\hline \multicolumn{6}{|c|}{ No. 2 Initial rainfall sample on $9 / 16 / 1999$} \\
\hline $64 \pm 4$ & $\begin{array}{c}20 \pm 1 \\
{[31 \pm 3]}\end{array}$ & $\begin{array}{c}44 \pm 4 \\
{[69 \pm 8]}\end{array}$ & $104 \pm 18$ & $\begin{array}{c}15 \pm 5 \\
{[14 \pm 5]}\end{array}$ & $\begin{array}{c}89 \pm 19 \\
{[86 \pm 23]}\end{array}$ \\
\hline \multicolumn{6}{|c|}{ No. 3 Synthetic sample $\left(100 \mu \mathrm{g}^{-1}\right.$ of Fe $)$} \\
\hline $41 \pm 1$ & $\begin{array}{c}40 \pm 1 \\
{[98 \pm 4]}\end{array}$ & $\begin{array}{c}1 \pm 2 \\
{[2 \pm 4]}\end{array}$ & - & - & - \\
\hline \multicolumn{6}{|c|}{ No. 4 Synthetic sample $\left(100 \mu \mathrm{g} \mathrm{l}^{-1}\right.$ of $\mathrm{Fe}$ and $200 \mu \mathrm{g} \mathrm{l^{-1 }}$ of HA) } \\
\hline $62 \pm 2$ & $\begin{array}{c}62 \pm 1 \\
{[100 \pm 4]}\end{array}$ & $\begin{array}{c}0 \pm 2 \\
{[0 \pm 4]}\end{array}$ & $91 \pm 6$ & $\begin{array}{c}37 \pm 9 \\
{[41 \pm 10]}\end{array}$ & $\begin{array}{c}54 \pm 11 \\
{[59 \pm 12]}\end{array}$ \\
\hline
\end{tabular}

The sample on the filter was stored in a desiccator and extracted with 0.1 $\mathrm{M} \mathrm{HCl}$. Figures in brackets indicate the percentage of the extracted concentration (B) and A - B to the total concentration (A).

results were used for the speciation of iron, as described later.

\section{Humic substances in rain water samples}

In the presence of a low concentration $\left(\leq 200 \mu \mathrm{g} \mathrm{l}^{-1}\right)$ of HA, iron associated with HA can be determined as a labile form by our catalytic method. ${ }^{3}$ Therefore, HSs in rain water were determined by the spectrofluorometric method, ${ }^{11}$ although this method determines the sum of HA and fulvic acid (FA). HSs in rain-water samples were characterized by measurements of the fluorescence emission spectra in excitation at $270 \mathrm{~nm}$. Similar emission spectra with a maximum emission at around $450 \mathrm{~nm}$ were obtained for the Wako HA reagent (Fig. 2, a) and the natural samples (b and c), indicating that the HSs were estimated as HA. A similar emission spectrum, ascribed to HAlike substances, was reported for rain water collected in Germany. ${ }^{15}$ However, the identification of HA and FA requires further study, because their chemical and physical properties may be dependent on their origin.

\section{Fractionation results of natural and synthetic rain water samples}

Figure 3 shows the fractionation results of iron and HA for the natural rain water samples. For all of the natural samples, iron was found in the molecular fraction $\left(\mathrm{MW}<10^{3}\right)$ and the particle fraction $(\geq 0.45 \mu \mathrm{m})$. The initial rainfall samples contained low concentration of labile iron in the molecular fraction and a higher concentration of non-labile iron in the particle fraction. Labile iron was also found in the particle fraction for the initial rainfall samples on $1 / 19 / 1999$ and $9 / 19 / 1999$, although it was not detected for the sample on 1/24/1999. The total concentration of iron in the successive rainfall sample was much lower than that in the initial rainfall sample, probably caused by the rainout and/or washout of airborne particulate matter (APM) containing iron. ${ }^{16}$ The size-distribution pattern of iron in the successive rainfall sample was similar to that of rainwater samples collected in Germany. ${ }^{9}$ The molecular fraction contained labile iron and an insignificantly non-labile one.

Figure 4 shows the fractionation results of iron and HA in synthetic samples. Iron-rich synthetic samples (Fig. 4, a and c) contained iron in the molecular and particle fractions,

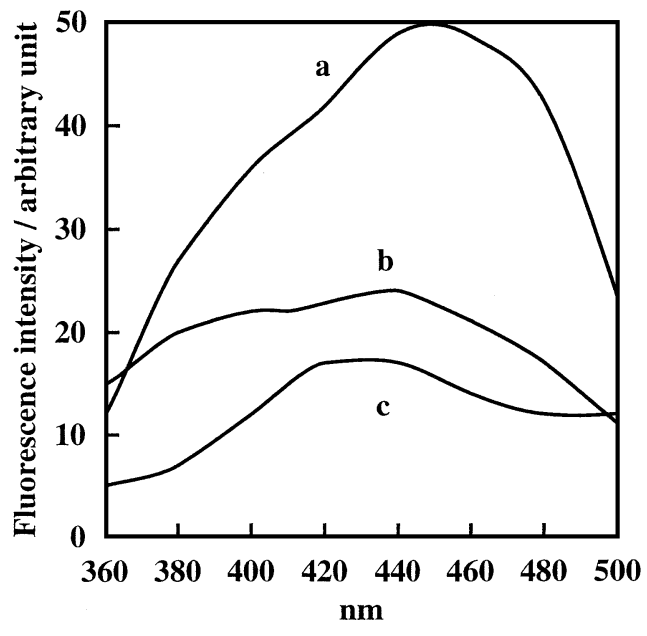

Fig. 2 Fluorescence emission spectra of a humic acid reagent and rain-water samples in excitation at $270 \mathrm{~nm}$. a, $200 \mu \mathrm{g} \mathrm{l^{-1 }}$ of humic acid (Wako); b and c, original rain water samples on 1/19/1999 and 1/24/1999, respectively. Emission from the reagent blank was subtracted and spectra were smoothed out.

respectively, as those in the natural samples. A loss of iron was found in the storage of these synthetic samples. We considered that the loss was caused by the adsorption of non-labile hydrated iron colloids on the inner wall of the storage bottle. ${ }^{3}$ The loss of HA was also caused by adsorption. On the other hand, the iron-lean synthetic sample (Fig. 4, d) contained only labile iron species and gave a good total recovery.

Humic acid was found in initial rainfall samples and not in a successive rainfall sample (Fig. 3). Therefore, HA may exist as APM and/or be associated with APM. For the natural and synthetic samples, iron and HA coexisted in the particle fraction, indicating the formation of humic iron aggregates. ${ }^{13}$ The size-distribution patterns of HA were similar among the sampling dates for the higher MW and particle fractions, whereas they were different for the lower MW fractions $\left(\mathrm{MW}<10^{4}\right)$. HA in the synthetic samples (Fig. 4) was found in the fractions of $\mathrm{MW} \geq 10^{4}$ as that in the natural sample, although it was scarcely found in the lower MW fractions. Such a difference in the pattern suggests that the physical and chemical properties of natural HSs may differ depending on the origin and/or their concentrations.

Based on the above results, iron species in the natural samples are characterized in the following sections.

\section{Labile iron in molecular fraction}

From a chemical equilibrium, $\mathrm{FeOH}^{2+}$ and $\mathrm{Fe}(\mathrm{OH})_{2}{ }^{+}$were reported as being predominant iron species in rain water. ${ }^{9}$ However, the validity of these species has not been discussed based on their concentrations in the natural rain samples. Our catalytic method ${ }^{3}$ can directly determine $\left[\mathrm{Fe}^{3+}\right]+\left[\mathrm{FeOH}^{2+}\right]+$ $\left[\mathrm{Fe}(\mathrm{OH})_{2}^{+}\right]$as labile iron. Therefore, the concentration of labile iron in the molecular fraction $\left(\mathrm{MW}<10^{3}\right)$ for the natural and synthetic samples with different values of $\mathrm{pH}$ was compared with $\left[\mathrm{FeOH}^{2+}\right]+\left[\mathrm{Fe}(\mathrm{OH})_{2}{ }^{+}\right]$calculated from the chemical equilibrium ${ }^{3}$ among $\mathrm{Fe}^{3+}, \mathrm{FeOH}^{2+}, \mathrm{Fe}(\mathrm{OH})_{2}{ }^{+}$and aqueous and amorphous $\mathrm{Fe}(\mathrm{OH})_{3}$ without considering the formation of polynuclear species. Figure 5 shows the relationship between the labile iron concentration and the $\mathrm{pH}$ in natural and synthetic rain-water samples. The concentration of labile iron roughly agrees with the calculated one, supporting the formation of the 

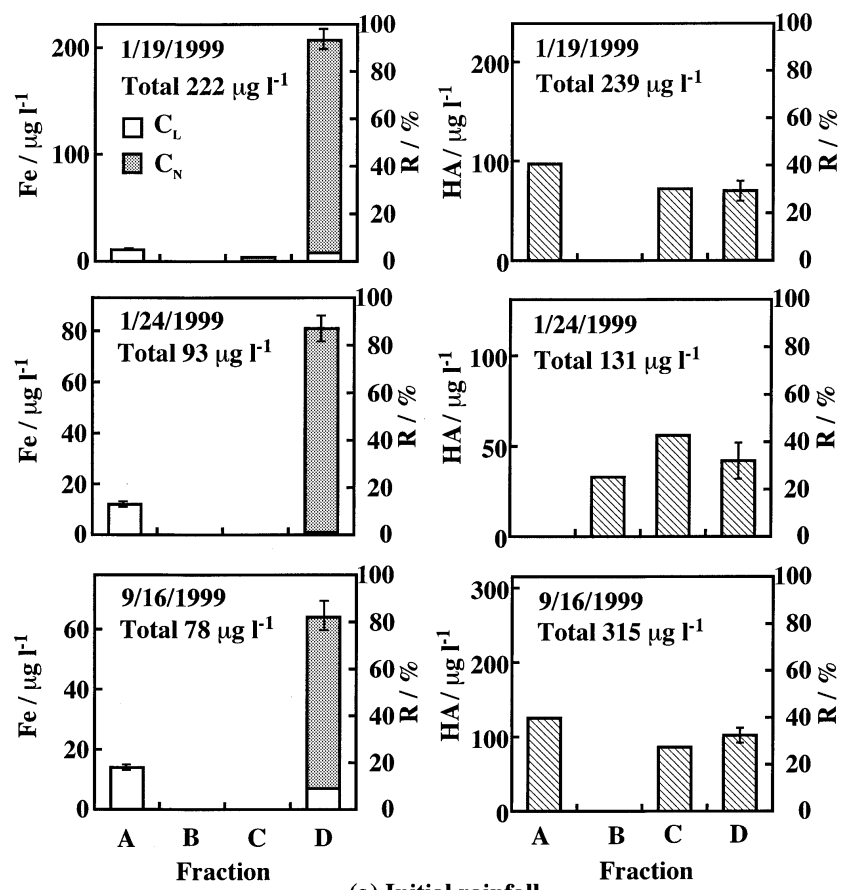

(a) Initial rainfall

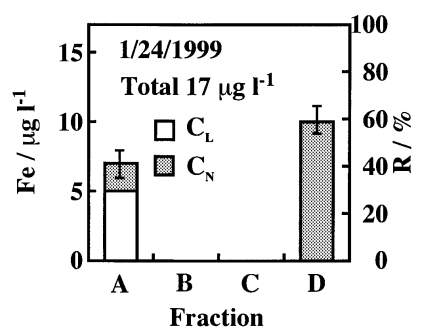

(b) Successive rainfall

Fig. 3 Fractionation results of the concentrations of labile $\left(C_{\mathrm{L}}\right)$ and non-labile $\left(C_{\mathrm{N}}\right)$ iron and $\mathrm{HA}$ and their ratios $(R)$ to the total concentration for natural rain water samples. A, MW $<10^{3}$; B, $10^{3} \leq \mathrm{MW}<10^{4} ; \mathrm{C}, \mathrm{MW} \geq 10^{4}$ - particle size $<0.45 \mu \mathrm{m} ; \mathrm{D}, \geq 0.45 \mu \mathrm{m}$. I, range of determination error $\left(\mu \mathrm{g}^{-1}\right)$.

labile iron by hydrolysis in the natural samples. The above speciation results for labile iron in the molecular fraction of the initial rainfall samples (1/19/1999 and 9/16/1999) are summarized in Table 2 together with the results for the particle fraction.

\section{Labile iron in particle fraction}

Labile iron in the particle fraction found for the natural samples was reproducible for the synthetic sample with iron and HA (Fig. 4, c), but not for that with iron alone. Therefore, the labile iron is explicable by the formation of labile humic iron. ${ }^{3}$ A change in the size-distribution (Fig. 4, b and c) of HA indicated that iron contributed to the aggregation of HA. These results support the aggregation model ${ }^{17,18}$ of metal-HA in which HA molecules are complexed with trace iron (and other metals) and thereby aggregated. The labile iron in the particle fraction probably binds at proton-exchangeable site(s) of a HA molecule, which exists predominantly on the surface of aggregates. The above speciation results for labile iron in the particle fraction are summarized in Table 2.

For a synthetic sample (Fig. 4, d) containing iron with a concentration near to that in the successive rainfall water, iron species with $\mathrm{MW} \geq 10^{4}$ were labile, and obviously different from

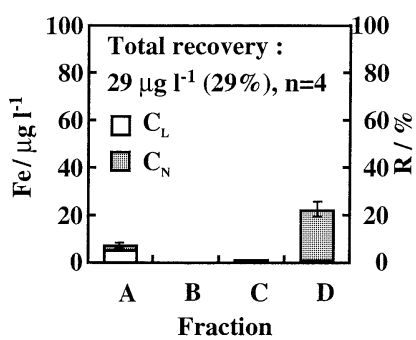

(a) $100 \mu \mathrm{g} \mathrm{Fe}(\mathrm{III}) \mathrm{l}^{-1}$

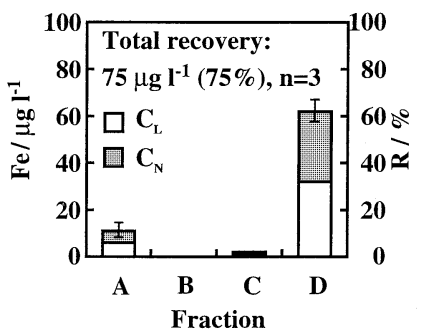

(c) $100 \mu \mathrm{g} \mathrm{Fe}$ (III) $\mathrm{l}^{-1}$ and $200 \mu \mathrm{g} \mathrm{HA} \mathrm{I}^{-1}$

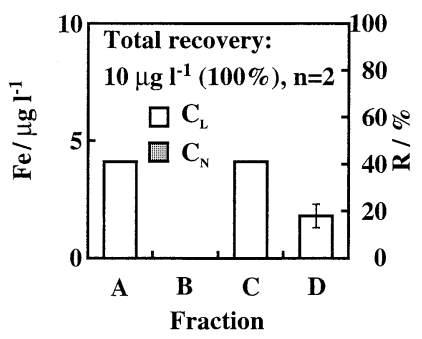

(d) $10 \mu \mathrm{g} \mathrm{Fe}(\mathrm{III}) \mathrm{l}^{-1}$

Fig. 4 Fractionation results of the concentrations of labile $\left(C_{\mathrm{L}}\right)$ and non-labile $\left(C_{\mathrm{N}}\right)$ iron and $\mathrm{HA}$ and their ratios $(R)$ to the total concentration in synthetic rain water samples with $\mathrm{pH}$ 4.5. A, $\mathrm{MW}<10^{3} ; \mathrm{B}, 10^{3} \leq \mathrm{MW}<10^{4} ; \mathrm{C}, \mathrm{MW} \leq 10^{4}$ - particle size $<0.45 \mu \mathrm{m}$; D, $\geq 0.45 \mu \mathrm{m}$. I, reproducibility $\left(\mu \mathrm{g} \mathrm{l}^{-1}\right)$ of for samples prepared on separate days.

the other natural and synthetic samples. This type of iron may be active amorphous iron(III) hydroxide, ${ }^{19}$ and probably become non-labile particulate forms after the aggregation during longer storage.

\section{Non-labile iron in particle fraction}

Most of the iron in the particle fraction of the natural samples existed as the non-labile form (Fig. 3). From the acid extraction result (Table 1) for the initial rainfall samples collected on $1 / 19 / 1999$ and $9 / 16 / 1999$, this type of iron was divided into acid-soluble and insoluble parts.

The content of iron in HA after washing complexed iron with $0.1 \mathrm{M} \mathrm{HCl}$ was reported as mineral binding capacity, ${ }^{14}$ e.g., 0.19 or $0.32 \mathrm{mmol} \mathrm{g}{ }^{-1}$ ( 0.01 or $0.02 \mathrm{~g} \mathrm{~g}^{-1}$ ) in HA isolated from peat or bog soil. This capacity gives 1 or $2 \mu \mathrm{g} \mathrm{l^{-1 }}$ as acid-insoluble iron associated with $89 \mu \mathrm{g} \mathrm{l}^{-1}$ of insoluble HA (A - B in Table 1, No. 2). This concentration of iron was negligible for our speciation method. Therefore, it was estimated that the acidinsoluble iron in the particle fraction mainly existed as silicates and oxides ${ }^{20,21}$ in APM introduced into rain water by the rainout and/or washout effect. From the aggregation model ${ }^{17,18}$ of metal-complexed organic compound, like HA, APM particles can be substrates on which HA molecules aggregate.

The acid extraction and speciation results (Table 1 and Fig. 4) for the synthetic samples suggested that the non-labile and acidsoluble iron in the particle fraction existed as aggregates of 


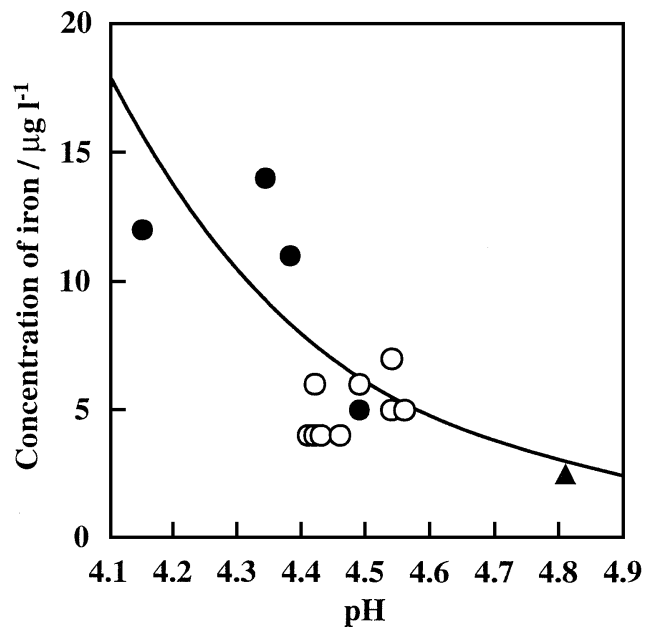

Fig. 5 Relationship between the labile iron concentration and the $\mathrm{pH} . \quad(\bullet, \circ)$ Labile iron in the $\mathrm{MW}<10^{3}$ fraction of natural and synthetic rain-water samples, respectively, ( $\mathbf{\Lambda})$ cationic iron in natural samples collected in Germany ${ }^{9}$ and (line) $\left[\mathrm{FeOH}^{2+}\right]+[\mathrm{Fe}$ $(\mathrm{OH})_{2}{ }^{+}$calculated from equilibrium data. ${ }^{3}$

iron(III) hydroxide and humic iron. In this case, humic iron was present in its aggregates, and was not complexed on them.

The above speciation results for the particle fraction are summarized in Table 2. In Table 2, it is noted that the concentration of the non-labile part of acid-soluble iron should be calculated by subtracting the labile concentration (Fig. 3) from the acid-soluble value (Table 1), because the labile part is also soluble in $0.1 \mathrm{M} \mathrm{HCl}$. For example, from the data in Fig. 3 and Table $1,91-8=83 \mu \mathrm{g} \mathrm{l^{-1 }}$ is the concentration of non-labile and acid-soluble iron for the sample collected on 1/19/1999.

\section{Conclusion}

A catalytic spectrophotometric method combined with size fractionation and acid decomposition was successfully applied to the speciation of iron in rain water. Acid extraction with 0.1 $\mathrm{M} \mathrm{HCl}$ was useful to characterize iron in the particle fraction $(\geq$ $0.45 \mu \mathrm{m})$. From the speciation results, iron in the molecular fraction $\left(\mathrm{MW}<10^{3}\right)$ was present as labile hydroxo iron ions. Labile iron in the particle fraction was characterized as iron complexed on humic iron aggregates. Non-labile iron in this fraction was estimated as acid-soluble iron in hydroxide and humic iron aggregates and as acid-insoluble iron in silicates and oxides.

\section{Acknowledgements}

This work was partly supported by a Grant-in-Aid for Scientific Research No. 10650794 from the Ministry on Education, Science, Sports and Culture of Japan. We thank Miss Yukiko Honda and Mr. Kazuhiro Tachikawa for their experimental assistance throughout this work.

\section{References}

1. B. T. Hart and T. Hines, "Trace Elements in Natural
Table 2 Speciation results of iron in initial rainfall samples collected on 1/19/1999 (No. 1) and 9/16/1999 (No. 2)

\begin{tabular}{|c|c|c|c|c|c|}
\hline \multirow{2}{*}{$\begin{array}{l}\text { Size- } \\
\text { fractionation }\end{array}$} & \multirow{2}{*}{$\begin{array}{c}\text { Catalytic } \\
\text { determination }\end{array}$} & \multirow{2}{*}{$\begin{array}{c}\text { Acid } \\
\text { extraction }\end{array}$} & \multirow{2}{*}{$\begin{array}{c}\text { Chemical } \\
\text { form }^{\mathrm{a}}\end{array}$} & \multicolumn{2}{|c|}{ Abundance, ${ }^{\mathrm{b}} \%$} \\
\hline & & & & No. 1 & No. 2 \\
\hline $\mathrm{MW}<10^{3}$ & Labile & - & $\begin{array}{l}\mathrm{FeOH}{ }^{2+} \text { and } \\
\mathrm{Fe}(\mathrm{OH})_{2}{ }^{+}\end{array}$ & 5 & 18 \\
\hline$\geq 0.45 \mu \mathrm{m}$ & Labile & Soluble & HI on HIA & 4 & 9 \\
\hline$\geq 0.45 \mu \mathrm{m}$ & Non-labile & Soluble & $\begin{array}{l}\mathrm{Fe}(\mathrm{OH})_{3} \text { and } \\
\mathrm{HI} \text { in HIA }\end{array}$ & 37 & 17 \\
\hline$\geq 0.45 \mu \mathrm{m}$ & Non-labile & Insoluble & $\begin{array}{l}\text { Oxides and } \\
\text { silicates }\end{array}$ & 52 & 56 \\
\hline
\end{tabular}

a. HI: humic iron; HIA: humic iron aggregates.

b. Abundance indicates mass percentage of iron with different chemical forms to total iron (refer to data in Fig. 3 and Table 1).

Waters", ed. B. Salbu and E. Steinnes, Chap. 9, 1995, CRC Press, Boca Raton, 206.

2. T. M. Florence, "Trace Element Speciation: Analytical Methods and Problems", ed. G. E. Batley, Chap. 4, 1989, CRC Press, Boca Raton, 77 - 116.

3. S. Kawakubo, Y. Hagihara, Y. Honda, and M. Iwatsuki, Anal. Chim. Acta, 1999, 388, 35.

4. M. Hiraide, Anal. Sci., 1992, 8, 453.

5. W. Ködel, M. Dassenakis, J. Lintelmann, and S. Padberg, Pure Appl. Chem., 1997, 69, 1571.

6. H. Hara, E. Ito, T. Katou, Y. Kitamura, T. Komeiji, M. Oohara, T. Okita, K. Sekiguchi, K. Taguchi, M. Tamaki, Y. Yamanaka, and K. Yoshimura, Bull. Chem. Soc. Jpn., 1990, 63, 2691.

7. T. M. Florence, J. Electroanal. Chem., 1970, 26, 293.

8. Z. Gao and K. S. Siow, Talanta, 1996, 43, 727.

9. H. Hofmann, P. Hoffmann, and K. H. Lieser, Fresenius $J$. Anal. Chem., 1991, 340, 591.

10. S. Kawakubo, M. Yamamoto, and T. Fukasawa, J. Japan Soc. Air Pollut., 1994, 29, 196.

11. G. L. Brun and D. L. D. Milburn, Anal. Lett., 1977, 10, 1209.

12. T. Kyotani and M. Iwatsuki, Anal. Sci., 1998, 14, 741.

13. K. Goto, T. Yotsuyanagi, and M. Nagayama, Kogyo Kagaku Zasshi, 1969, 72, 1871.

14. G. Davies, A. Fataftah, A. Cherkasskiy, E. A. Ghabbour, A. Radwan, S. A. Jansen, S. Kolla, M. D. Paciolla, L. T. Sein, Jr., W. Buermann, M. Balasubramanian, J. Budnick, and B. Xing, J. Chem. Soc., Dalton Trans., 1997, 4047.

15. S. Patsayeva and R. Reuter, Proc. SPIE - Int. Soc. Opt. Eng., 1995, 2586, 151

16. Y. Ambe and M. Nishikawa, Atoms. Environ., 1986, 20, 1931.

17. D. J. Mackey and A. Zirino, Anal. Chim. Acta, 1994, 284, 635.

18. M. Hiraide, M. Ishii, and A. Mizuike, Anal. Sci., 1988, 4, 605.

19. C. F. Baes, Jr. and R. E. Mesmer, "The Hydrolysis of Cations", 1976, Wiley-Interscience, New York, 234.

20. T. Fukasawa and M. Iwatsuki, J. Japan Soc. Air Pollut., $\mathbf{1 9 8 5}, 20,23$.

21. J. Hlavay, K. Polyák, A. Molnár, and E. Mészáros, Analyst [London], 1998, 123, 859. 